Primljen / Received: 27.8.2012.

Ispravljen / Corrected: 5.11.2012.

Prihvaćen / Accepted: 29.11.2012.

Dostupno online / Available online: 15.12.2012.

\section{Research of asphalt layer bonding in Lithuanian pavement structures}

\section{Authors:}

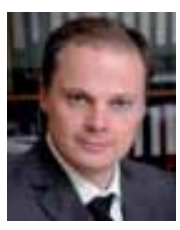

Asst.Prof. Audrius Vaitkus audrius.vaitkus@vgtu.It

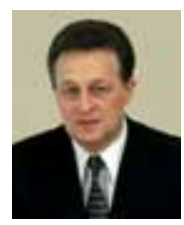

Prof.dr. Donatas Čygas donatas.cygas@vgtu.It

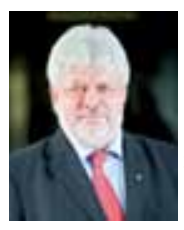

${ }^{2}$ Prof. dr. Alfredas Laurinavičius alfredas.laurinavicius@vgtuu.lt

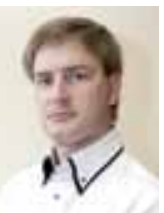

dr. Viktoras Vorobjovas viktoras.vorobjovas@vgtu.lt

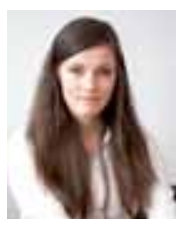

${ }^{1}$ Rita Kleizienè, PhD student rita.kleiziene@vgtu.It

${ }^{1}$ Roads Research Institute

Vilnius Gediminas Technical University, Lithuania

\section{${ }^{2}$ Department of Roads}

Vilnius Gediminas Technical University, Lithuania

\author{
Preliminary note \\ Audrius Vaitkus, Donatas Čygas, Alfredas Laurinavičius, Viktoras Vorobjovas, Rita Kleizienẻ
}

\section{Research of asphalt layer bonding in Lithuanian pavement structures}

The strength and durability of road pavement structures are directly influenced by the way in which asphalt layers are bonded. An insufficient bond between pavement layers leads to wearing, tearing, pavement deterioration, and cracking, and the pavement life span is reduced. The quality of bond between pavement layers was determined by direct shear test, using the so called Leutner method, without normal stress in specimen. Test samples were taken at various locations along the Lithuanian road network, from pavements characterized by standard asphalt structure, and reinforced asphalt structure in which geosynthetic materials are used in interlayers

\author{
Key words: \\ asphalt pavement, bond between pavement layers, Leutner method
}

Prethodno priopćenje

Audrius Vaitkus, Donatas Čygas, Alfredas Laurinavičius, Viktoras Vorobjovas, Rita Kleizienè

\section{Istraživanje veziva asfaltnih slojeva kolničkih konstrukcija u Litvi}

Način povezivanja slojeva asfaltne kolničke konstrukcije izravno utječe na čvrstoću i trajnost kolnika. Ako veza nije pravilno izvedena, kolnik postaje sklizak, dolazi do habanja, pucanja, propadanja kolnika i pojave pukotina te smanjenja vijeka trajanja. Kvaliteta veze između slojeva kolnika odredena je direktnim ispitivanjem na smicanje, takozvanom Leutnerovom metodom bez pojave normalnog naprezanja u uzorku. Uzorci za ispitivanja uzeti su na različitim lokacijama cestovne mreže u Litvi, i to iz kolnika s klasičnom asfaltnom konstrukcijom te s pojačanom asfaltnom konstrukcijom primjenom geosintetika u međuslojevima.

Ključne riječi:

asfaltni kolnik, veza slojeva kolničke konstrukcije, Leutnerova metoda

Vorherige Mitteilung

Audrius Vaitkus, Donatas Čygas, Alfredas Laurinavičius, Viktoras Vorobjovas, Rita Kleizienè

\section{Untersuchung des Verbunds von Asphaltschichten in litauischen Fahrbahnstrukturen}

Der Verbund von Asphaltschichten der Fahrbahnstruktur hat einen direkten Einfluss auf die Festigkeit und die Haltbarkeit der Fahrbahn. Unsachgemäß ausgeführte Schichtenverbunde können eine rutschige Oberfläche der Fahrbahn verursachen, während möglicherweise auftretende Verschleißung, Rissbildung und andere Beschädigungen zu einer Verringerung der erwarteten Lebensdauer führen können. Die Qualität der Schichtenverbunde des Straßenbelags ist durch Abscherversuche ermittelt, mit Hilfe der sogenannten Leutner-Methode, die ohne das Auftreten von Normalspannungen ausgeführt wird. Versuchsproben sind an verschiedenen Standorten des Straßennetzes in Litauen entnommen worden, und zwar sowohl für Fahrbahnen mit klassischen Fahrbahnstrukturen, als auch für Asphaltbeläge, die durch die Anwendung von geosynthetischen Materialen in den Zwischenschichten verstärkt wurden.

Schlüsselwörter:

Asphaltfahrbahn, Schichtenverbunde der Fahrbahnstruktur, Leutner-Methode 


\section{Introduction}

The bonding of asphalt layers is a significant factor that directly influences the strength and durability of pavements. Thie bonding of asphalt layers is influenced by the size of aggregates used in asphalt mix, by the type of asphalt mix and binder, by the quantity of bitumen emulsion, and by the type of construction technology used [1,2]. Due to insufficient bonding between asphalt layers, the upper asphalt layer may be displaced, under the effect of shear force, parallel to the asphalt binder, and the asphalt binder can be displaced parallel to the asphalt base layer. In that case, the asphalt pavement structure is affected by corrugation, slippage and transverse cracking. The pavement distress usually occurs at the acceleration/deceleration and turning zones. The asphalt pavement life span decreases because of insufficient bonding of asphalt layers. The necessary bearing capacity, strength, and durability of pavement structures can be obtained if the bond between asphalt layers is appropriate [1,2]. If bonding is sufficient, all asphalt layers in pavement act as a monolithic structure, and the largest stress from wheel load is concentrated at the bottom of asphalt base course. In such a case the cracking also starts from the asphalt base course. When the bonding is insufficient, each asphalt layer operates separately from the others, and the maximum stress is concentrated at the bottom of each asphalt layer.

The bonding between asphalt layers is conditioned by the friction and interlocking of layers. The friction is reduced by an excessive quantity of binder between the layers, when a binder coat is formed, which does n't allow the contact between separate asphalt layers. The bonding between asphalt layers depends on friction, bonding, and interlocking of layers. There are three types of asphalt layer bonding [3]:

- Sufficiently bonded - asphalt layers act as a monolithic structure. A large shear stress is created and no deformations (displacements) are developed. However, this is a theoretical model, because in practice the bonding plane of asphalt layers is always represented by a smaller or larger deformation.

- Partially bonded - depends on the interlocking strength. The shear stress and deformations (displacements) of various sizes occur between layers. In case of strong interlocking, the large shear stress and small deformations are registered. Conversely, if the interlocking is weak, the shear stress is small and the deformation is substantial.

- Insufficiently bonded - the friction and bonding occur only as a result of the load and self-weight of layers. Small shear stresses and large deformations occurs between the layers.

K. Schulze [4] has demonstrated that insufficient bonding between asphalt layers can cause corrugation and rutting of pavement. R. Weber [5] states that cracks in asphalt pavement occur because of insufficient bonding of asphalt layers. J. Eisenmann and U. Neumann [6] report that an optimal bonding is necessary to obtain an asphalt pavement strength that is sufficient to prevent rutting. G. King and R. May [7] have determined that the deformation of asphalt pavement layers increases significantly if the layer bonding decreases from $100 \%$ to $90 \%$, which results in a premature deterioration of asphalt pavement. C. J. Roffe and F. Chaignon [8] state that the life cycle of asphalt pavement can be reduced by seven or eight years if the asphalt layer bonding is inadequate. R. Dübner and W. Glet [9] assert that insufficient bonding between layers can influence deformation and crumbling of the pavement. L. Tashman and others [10] state that the asphalt layers bonding strength depends on the surface preparation, the amount of binder emulsion sprayed, and the time interval between binder emulsion spraying and the placement of an another asphalt layer. In 2011, A. Vaitkus et al. [11] established that there is no difference in the asphalt layers bonding strength as related to the sampling location - in the wheel-path or in-between the wheel-path of the same road. The dependence of the stress and deformation distribution in pavement structure on the traffic volume and climate was tested on a road test section $[12,13]$.

\section{Determination of asphalt layer bonding strength}

The asphalt layer bonding strength can be determined by several methods. The shearing test is most often used in practice, while the pull-off and torque tests are less common (Figure 1). The shearing test is most often used in order to evaluate the bonding strength between asphalt layers. The shearing test can be performed either without normal stress (direct shear test), and with normal stress (simple shear test):

1. The direct shear test: the Leutner test, the parallel-layer direct shear test, the LBC test, the De Bondt test, the U.S. National Asphalt Technology Center Shearing test (NCAT), the FDOT test, the lowa test, the Rommanoshi test, the AlQadi test, the Asher test, and the SST- Superpave Shear Test.

2. The simple shear test: the MCS trial, the ASTRA trial, and the SST trial.



Figure 1. Methods used to determine bonding strength of asphalt layers [3] 
In 1979, R. Leutner described a direct shear test method for determining the asphalt layer bonding strength [14]. The Leutner test is one of the most commonly used direct shear methods, and is widely used in many countries. In Switzerland, Austria, and Germany it has been accepted as the national standard for evaluating strength of asphalt layers. The bonding of layers is evaluated by measuring the maximum shear force (kN) and shear flow (mm).

In Germany, the bonding strength of asphalt layers is determined by performing the Leutner test according to the document TP asphalt-StB Teil 80 (direct shear test). In this country, the minimum value of the asphalt layer bonding strength is regulated by the document ZTV Asphalt-StB 07 [15]: between the asphalt wearing course and binder - no less than $15 \mathrm{kN}$; between all other asphalt layers - no less than $12 \mathrm{kN}$. The recommended limit values between the wearing course and binder is $2,0-4,0 \mathrm{~mm}$, and between the binder and base course 1,5-3,0 m Recommended limit values for shear flow are given in ZTV M-V and Arbit Nr. 60.

\section{Experimental research}

The experimental research was conducted at the laboratory of the Road Research Institute of the Vilnius Gediminas Technical University in 2010 and 2011. Direct shear tests were performed on samples prepared in laboratory, and on samples (cores) taken from Lithuanian roads and city streets.

\subsection{Test results for samples made in laboratory}

In the laboratory, the asphalt wearing course and binder samples were prepared by applying different types and quantities of bitumen emulsion between the layers, and using different compaction levels for the asphalt wearing course. The roller compactor was used to compact the samples. The wearing course was made either of the asphalt concrete for wearing courses with maximum grain size of $11 \mathrm{~mm}$, designed for normal loads ( $A C 11$ VN), or the asphalt concrete for wearing course with maximum grain size of $11 \mathrm{~mm}$, designed for heavy loads (AC 11 VS). The binder was made of the asphalt concrete for binders with a maximum grain size of $16 \mathrm{~mm}$, designed for normal loads (AC 16 AN).

The asphalt binder, $7 \mathrm{~cm}$ in thickness, was prepared during the first day of the testing. The asphalt wearing layer, $4 \mathrm{~cm}$ in thickness, was prepared a day after. Thus two slabs $410 \mathrm{~mm}$ long, $210 \mathrm{~mm}$ wide, and $11 \mathrm{~cm}$ thick, were prepared. Different types and quantities of bitumen emulsion were sprayed in between the asphalt layers. The emulsion's working temperature was $40^{\circ} \mathrm{C}$. Asphalt layer slabs, without the bitumen emulsion in between the layers, were also made for comparison purposes. The compaction level of the asphalt wearing course was $97 \%$ or $100 \%$, while the compaction level for the asphalt binder layer was $97 \%$ for all samples. Three 150 $\mathrm{mm}$ diameter asphalt cores were drilled from each asphalt slab. The interlayer bonding was measured in accordance with the Asphalt technical testing guidelines, Part 80 (GermanTechnische Prüfvorschriften für asphalt, TP Asphalt-StB Teil 80). The tests were performed in the standard Marshall compactor, with shearing mould. The constant static load of $50 \mathrm{~mm} / \mathrm{min}$ was applied. Before the test, asphalt cores were stored at the temperature of $20^{\circ} \mathrm{C}$ for 24 hours. Sample combinations made in laboratory and test results are presented in Table 1.

Table 1. Combinations of samples made in laboratory and test results

\begin{tabular}{|c|c|c|c|c|c|c|c|c|}
\hline \multirow{2}{*}{$\begin{array}{c}\text { Testing } \\
\text { combination }\end{array}$} & \multirow{2}{*}{$\begin{array}{l}\text { Interlayer } \\
\text { bonding } \\
\text { material }\end{array}$} & \multirow{2}{*}{$\begin{array}{c}\text { The quantity } \\
\text { of bonding } \\
\text { material } \\
{\left[\mathrm{g} / \mathrm{m}^{2}\right]}\end{array}$} & \multirow{2}{*}{$\begin{array}{c}\text { Asphalt wearing } \\
\text { course mix } \\
\text { (compression level) } \\
{[\%]}\end{array}$} & \multirow{2}{*}{$\begin{array}{c}\text { Asphalt } \\
\text { binder mix } \\
\text { (compression level) } \\
{[\%]}\end{array}$} & \multicolumn{2}{|c|}{$\begin{array}{c}\text { Shear force } \\
{[\mathrm{kN}]}\end{array}$} & \multicolumn{2}{|c|}{$\begin{array}{l}\text { Shear flow } \\
\text { [mm] }\end{array}$} \\
\hline & & & & & $\begin{array}{l}\text { After } \\
2 \text { days }\end{array}$ & $\begin{array}{c}\text { After } \\
10 \text { days }\end{array}$ & $\begin{array}{l}\text { After } \\
2 \text { days }\end{array}$ & $\begin{array}{l}\text { After } \\
10 \text { days }\end{array}$ \\
\hline 1 & - & - & AC 11 VN (97\%) & \multirow{10}{*}{ AC 16 AN (97\%) } & 21,67 & 36,73 & 1,93 & 2,80 \\
\hline 2 & - & - & AC 11 VN (100\%) & & 21,97 & 41,50 & 2,93 & 1,73 \\
\hline 3 & - & - & AC 11 VS (97\%) & & 14,23 & 28,27 & 2,33 & 1,70 \\
\hline 4 & - & - & AC 11 VS (100\%) & & 14,30 & 33,53 & 1,90 & 1,87 \\
\hline 5 & C 60 BF 1-S & 90 & AC 11 VN (97\%) & & 30,00 & 44,77 & 3,10 & 3,47 \\
\hline 6 & C 60 BF 1-S & 135 & AC 11 VN (97\%) & & 22,83 & 42,50 & 2,10 & 2,57 \\
\hline 7 & C 60 BF 1-S & 200 & AC 11 VN (97\%) & & 32,73 & 32,73 & 2,27 & 2,27 \\
\hline 8 & C 60 BP 1-S & 100 & AC 11 VN (97\%) & & 33,25 & 36,67 & 2,81 & 3,46 \\
\hline 9 & C 60 BP 1-S & 150 & AC 11 VN (97\%) & & 38,17 & 43,83 & 3,16 & 3,00 \\
\hline 10 & C 60 BP 1-S & 250 & AC 11 VN (97\%) & & 35,83 & 38,42 & 3,33 & 4,44 \\
\hline
\end{tabular}


The test results (Figure 2) show that the shear force varies in a wide interval, from $14,2 \mathrm{kN}$ to $44,8 \mathrm{kN}$. The minimum shear force was registered in combinations 3 and 4 , i.e. in samples in which the asphalt wearing course was AC 11 VS with the $97 \%$ and $100 \%$ compaction level, and no any bonding material was used in interlayer. The maximum shear force was registered in the combination $9(38,17 \mathrm{kN}$ after 2 days, and 43,83 kN after 10 days), i.e. in samples in which the asphalt wearing course was AC 11 VN with the $97 \%$ compaction level, and with the $150 \mathrm{~g} / \mathrm{m}^{2}$ bitumen emulsion in interlayer. Depending on the testing time, a $13 \%$ higher shear force was obtained after 10 days. Shear force results for asphalt wearing course samples subjected to $100 \%$ compaction were $13 \%$ (AC $11 \mathrm{VN}$ ) and 18 $\%$ (AC 11 VS) higher when compared to the $97 \%$ compaction level. The values of all asphalt wearing course samples made of AC 11 VN were higher by av. $26 \%$ (tested after 2 days) and av. $54 \%$ (tested after 10 days), when compared with values of the asphalt wearing course made of AC 11 VS. In this case, the bitumen emulsion was not used in the interlayer.

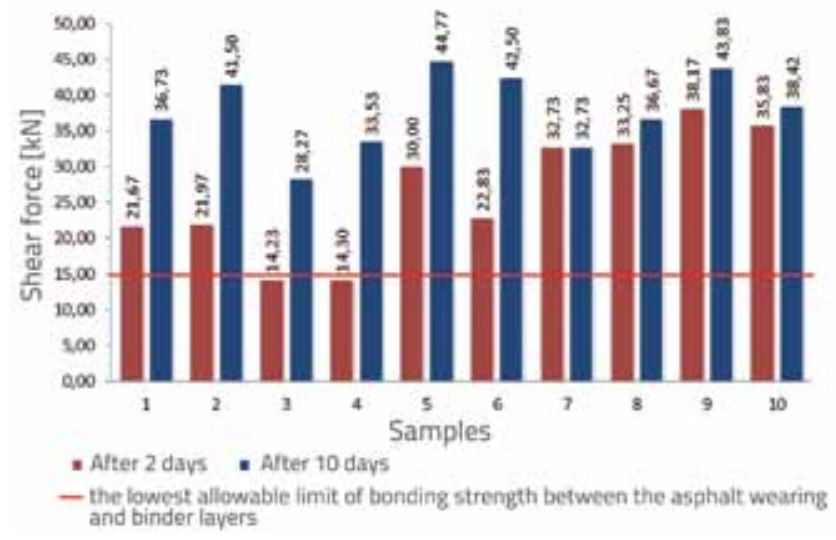

Figure 2. Distribution of shear force between the asphalt wearing course and binder in samples prepared in laboratory

The bonding strength was about $30 \%$ greater when bitumen emulsion C 60 BF 1-S was added to the asphalt interlayer, when compared to the situation without the bitumen emulsion (tested after 2 days No significant difference was revealed after 10 days. A significant difference in bonding strength was registered by comparing samples tested after 2 and 10 days, when bitumen emulsion was not used in the interlayer. In this case, the difference in bonding strength ranged from $69 \%$ to $134 \%$, depending on the type of the asphalt mix used in the wearing course, and on the compaction level. It was established that the shear force is much higher in samples with bitumen emulsion C $60 \mathrm{BP} 1-\mathrm{S}$, when compared to samples with bitumen emulsion C 60 BF 1-S. The difference in results 2 days after the compaction varies from $10 \%$ to $60 \%$, but no significant difference was obtained for samples tested 10 days after compaction.

It was established that the asphalt layer shear flow values ranged from $1,7 \mathrm{~mm}$ to $4,5 \mathrm{~mm}$. In samples with bitumen emulsion C 60 BF 1-S the shear flow varied from $2,1 \mathrm{~mm}$ to $3,5 \mathrm{~mm}$. The highest values were determined for samples containing the $90 \mathrm{~g} / \mathrm{m}^{2}$ emulsion, tested after 10 days. In samples with bitumen emulsion C 60 BP 1-S the shear flow varied from $2,8 \mathrm{~mm}$ to $4,5 \mathrm{~mm}$. The greatest value was determined for samples containing the $250 \mathrm{~g} / \mathrm{m}^{2}$ emulsion, tested after 10 days.

The analysis of the asphalt layer bonding strength results shows that after 10 days of asphalt compaction, the bonding strength was in all cases greater than $25 \mathrm{kN}$, and the shear flow was greater than $1.5 \mathrm{~mm}$. It should be noted that the use of bitumen emulsion leads to sufficient bonding of asphalt layers, but only the right amount of bitumen emulsion ensures good bonding and an allowable shear flow. Results are much more promising for polymer modified emulsions C 60 BP 1-S, when compared to bitumen emulsion C 60 BF 1-S.

\subsection{Test results for samples taken from roads and city streets}

In the scope of the testing, asphalt cores were taken from selected roads, and their bonding strength was tested on these cores in laboratory. The samples were taken on selected roads and streets, both in the wheel-path and in between the wheel-paths. These samples had either the geosynthetic interlayer, the stress absorbing membrane interlayer (SAMI), or the bitumen emulsion interlayer. The testing combinations and laboratory test results are presented in Table 2.

The asphalt cores were taken in accordance with the LST EN 12697-27:2002 standard, while the asphalt layer bonding strength was determined according to the Asphalt Testing Technical Directive-Part 80 (German-Technische Prüfvorschriften für asphalt, TP Asphalt-StB Teil 80). The asphalt layer bonding strength distribution is presented, for various testing combinations, in Figure 3.The thickness of asphalt wearing course cores varied from $3,6 \mathrm{~cm}$ to $6,2 \mathrm{~cm}$. The thickness of asphalt binder cores was greater than $8 \mathrm{~cm}$, and so the total thickness of cores was reduced to about $11,0 \mathrm{~cm}$. The analysis of the asphalt layer shear force distribution revealed that the shear force was greater than $15 \mathrm{kN}$ in 88 $\%$ of testing combinations (22 out of 25 ). In the remaining 3 testing combinations the results were distributed as follows: in combinations 6.1 and 8.1 the shear force was by $21 \%$ lower than the required value $(15 \mathrm{kN})$, and in the combination 5.2 it was by $20 \%$ lower than the required value(12 kN).The maximum shear force was registered in combinations 10.1 and 10.2 in the wheel-path of the road $\mathrm{Nr} .102$ where the asphalt wearing course is made of SMA $11 \mathrm{~S}$. The minimum shear force was established in the combination 5.2 which was taken in the wheel-path of the Eisiskiy Street. It was established from samples taken at the Plytines Street that the shear force is by $85 \%$ greater without geosynthetic interlayer (testing combination 3.2) when compared to situation with such interlayer (testing 
Table 2. Testing combinations and laboratory test results for samples taken from roads and city street

\begin{tabular}{|c|c|c|c|c|c|c|c|}
\hline \multirow{2}{*}{$\begin{array}{c}\begin{array}{c}\text { Testing } \\
\text { combi- } \\
\text { nation }\end{array} \\
1\end{array}$} & \multirow{2}{*}{$\begin{array}{c}\begin{array}{c}\text { Paving } \\
\text { year }\end{array} \\
2010\end{array}$} & \multicolumn{2}{|c|}{ Sampling location } & \multirow{2}{*}{$\begin{array}{c}\begin{array}{c}\text { Asphalt wearing } \\
\text { course mix }\end{array} \\
\text { AC } 16 \text { AS }\end{array}$} & \multirow{2}{*}{$\begin{array}{l}\text { Type of material in interlayer } \\
\text { SAMI (under binder layer) }\end{array}$} & \multirow{2}{*}{$\begin{array}{r}\begin{array}{r}\text { Shear } \\
\text { force } \\
\text { [kN] }\end{array} \\
24,40\end{array}$} & \multirow{2}{*}{$\begin{array}{r}\begin{array}{r}\text { Shear } \\
\text { flow } \\
\text { [mm] }\end{array} \\
5,90\end{array}$} \\
\hline & & Oslo Str., Vilnius & Pozition A & & & & \\
\hline 2 & 2005 & $\begin{array}{l}\text { Savanoriu Str., } \\
\text { Vilnius }\end{array}$ & Pozition A & SMA $11 \mathrm{~S}$ & SAMI (under wearing layer) & 24,60 & 6,10 \\
\hline 3.1 & \multirow[t]{2}{*}{2006} & \multirow{2}{*}{$\begin{array}{l}\text { Plytines Str., } \\
\text { Vilnius }\end{array}$} & \multirow[t]{2}{*}{ Pozition A } & \multirow[t]{2}{*}{ AC 11 VS } & $\begin{array}{l}\text { Pavegrid G100/100 } \\
\text { (under binder layer) }\end{array}$ & 16,40 & 2,20 \\
\hline 3.2 & & & & & Without geogrid & 30,30 & 3,40 \\
\hline 4.1 & \multirow{2}{*}{2007} & \multirow{2}{*}{$\begin{array}{l}\text { Kalvariju Str., } \\
\text { Vilnius }\end{array}$} & \multirow{2}{*}{ Pozition A } & \multirow{2}{*}{ SMA $11 \mathrm{~S}$} & $\begin{array}{l}\text { Pavegrid G100/100 } \\
\text { (under wearing layer) }\end{array}$ & 23,50 & 2,80 \\
\hline 4.2 & & & & & Without geogrid & 32,40 & 3,50 \\
\hline 5.1 & \multirow{3}{*}{2007} & \multirow{3}{*}{$\begin{array}{l}\text { Eisikių Str., } \\
\text { Vilnius }\end{array}$} & \multirow{3}{*}{ Pozition A } & \multirow{3}{*}{ SMA $11 \mathrm{~S}$} & $\begin{array}{c}\text { Hatelit C 40/17 } \\
\text { (under binder layer) }\end{array}$ & 20,10 & 1,80 \\
\hline 5.2 & & & & & $\begin{array}{l}\text { Armatex RSM 50/50 } \\
\text { (under binder layer) }\end{array}$ & 9,60 & 1,70 \\
\hline 5.3 & & & & & Without geogrid & 26,10 & 1,00 \\
\hline 6.1 & \multirow{2}{*}{2008} & \multirow{2}{*}{ Road Nr. 153} & Pozition A & \multirow{2}{*}{ AC 11 VS } & \multirow{2}{*}{ Without geogrid } & 11,83 & 1,78 \\
\hline 6.2 & & & Pozition B & & & 18,45 & 2,00 \\
\hline 7.1 & \multirow{2}{*}{2010} & \multirow{2}{*}{ Road Nr. 143} & Pozition A & \multirow{2}{*}{ AC $11 \mathrm{VN}$} & \multirow{2}{*}{ Without geogrid } & 17,82 & 2,55 \\
\hline 7.2 & & & Pozition B & & & 18,35 & 2,70 \\
\hline 8.1 & \multirow{2}{*}{2010} & \multirow{2}{*}{ Road Nr. 130} & Pozition A & \multirow{2}{*}{ AC 11 VS } & \multirow{2}{*}{ Without geogrid } & 11,85 & 2,05 \\
\hline 8.2 & & & Pozition B & & & 15,45 & 2,78 \\
\hline 9.1 & \multirow{2}{*}{2010} & Dopd No 120 & Pozition A & $A C 11 \mathrm{VC}$ & Withrut anogrid & 21,20 & 2,08 \\
\hline 9.2 & & mudutivi. 1200 & Pozition B & בע & 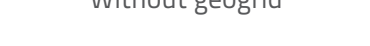 & 16,90 & 2,25 \\
\hline 10.1 & 2010 & ר 10 & Pozition A & CMAM 11C & Wlithout anorrid & 34,05 & 4,03 \\
\hline 10.2 & 2010 & nuadivis to & Pozition B & 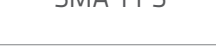 & 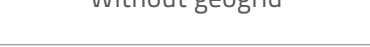 & 31,85 & 3,95 \\
\hline 11.1 & 2010 & 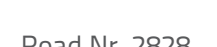 & Pozition A & C 11 VN & Wlithout angarid & 33,20 & 3,35 \\
\hline 11.2 & 2010 & RUdu IVI. $\angle 0 \angle O$ & Pozition B & AL II VIV & vartiour geogina & 25,35 & 4,05 \\
\hline 12.1 & 2010 & Dond Ner 0 & Pozition A & $A C 11 \mathrm{~V}$ & Without a & 19,45 & 3,95 \\
\hline 12.2 & 2010 & MUdu TVI. $\mathrm{H}_{4}$ & Pozition B & SO & 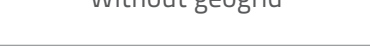 & 16,35 & 2,70 \\
\hline 13.1 & 2000 & $\mathrm{Bond} \mathrm{Ner} \mathrm{O}$ & Pozition A & CNAD 11C & Wlithout a sarid & 25,69 & 5,53 \\
\hline 13.2 & 2003 & RuduTVI. 114 & Pozition B & בוVIT IIT & 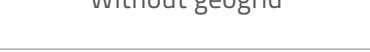 & 24,23 & 3,43 \\
\hline $\begin{array}{l}\text { Pozition o } \\
\text { Pozition A } \\
\text { Pozition B }\end{array}$ & $\begin{array}{l}\text { Ipling I } \\
\text { le whe } \\
\text { Neen } t\end{array}$ & on & & & & & \\
\hline
\end{tabular}

combination 3.1). Testing of samples selected from the Eisiskiu Street has revealed that the shear force is by about $30 \%$ greater in samples without the geosynthetic interlayer (testing combination 5.1), when compared to samples with the geogrid Hatelit C 40/17 (testing combination 5.3), while this shear force is as many as 2.7 times greater (testing combination 5.2) when compared to the sample with the Armatex RSM 50/70 geogrid. An insufficient asphalt layer bonding strength has also been identified in samples taken at the roads No. 153, No. 130, and No. 143. It was determined that the shear flow changes independently from testing combination, but is however influenced by the material used in interlayers. In $72 \%$ of testing combinations (18 out of 25 ) the shear flow ranged from $2,0 \mathrm{~mm}$ to $4,0 \mathrm{~mm}$. The analysis of samples taken at the Plytines Street has revealed that the shear flow is $35 \%$ lower with geosynthetic interlayer, than without this interlayer. The testing of samples taken at the Eisiskiu Street has shown that the shear force of samples without geosynthetics is greater by about $40 \%$ when compared to the Hatelit C 40/17 geogrid (testing combination 5.1), and the Armatex RSM 50/70 geogrid (testing combination 5.2). 


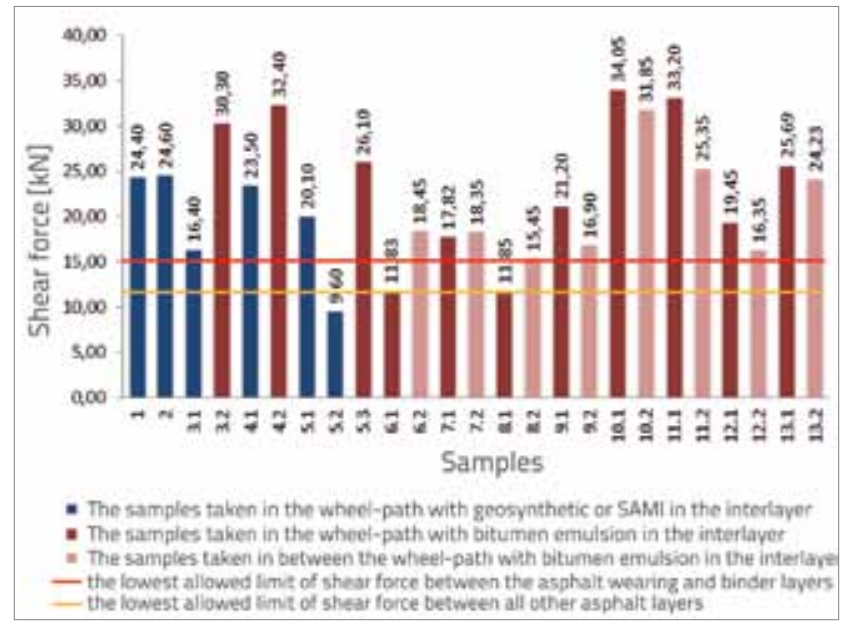

Figure 3. Distribution of shear force between asphalt layers in cores taken from roads and city streets

A relatively high shear flow range, exceeding the ZMT M-V recommendations, was identified in samples 1, 2 and 13.1. In samples 1 and 2, a special asphalt mix SAMI 0/5 was used for the interlayer, and the SMA $11 \mathrm{~S}$ mix was used for 13.1. It can be noticed that in testing combinations with the asphalt wearing course SMA 11 S (10.1, 10.2: road Nr. 102, and 13.1, 13.2: road Nr. A14) the shear flow was not significantly higher compared to other types of asphalt wearing courses. It was revealed that the shear flow changes independently from the sample taking location (wheel-path or between the wheel paths).

\section{REFERENCES}

[1] Raab, C., Partl, M. N., Halim, A. E.: Evaluation of interlayer shear bond devices for asphalt pavements, The Baltic Journal of Road and Bridge Engineering, 4(4), p.p. 186-195, 2009.

[2] Raab, C., Partl, M. N.: Interlayer Bonding of Binder, Base and Subbase Layers of Asphalt Pavements: Long-term Performance, Journal Construction and Building Materials, 23, p.p. 2926-2931, 2009.

[3] Frohmut, W., Ascher, D.: Untersuchungen zur Wirksamkeit des Haftverbundes und dessen Auswirkungen auf die Lebensdauer von Asphaltbefestigungen, Schlussbericht zum AiF-Projekt Nr. 13589 BR/1, Technische Universität Dresden, 2007.Schulze, K.: Asphaltbeton mit erhöhtem Füller-Bitumen-Verhältnis und dichter Belagsstruktur, Straßen- und Tiefbau Heft 11, 1979.

[4] Weber, R.: Rißbildungen in Asphaltstraßen als Folge mangelhaften Schichtver-bundes, Dissertation TU München, 1991.

[5] Eisenmann, J., Neumann, U.: Auswirkungen von Verbundstörungen auf die Spurrinnenbildung, Forschungsbericht Nr. 1444 (FE 07.151 G 91 K), Prüfamt für Bau von Landverkehrsflächen der TU München. 1993.

[6] King, G., May. R.: New Approaches to Tack Application, presentation made to the 83rd Annual Meeting of the Transportation Research Board, Washington, D. C., 2003.

[7] Roffe, J. C., and Chaignon, F.: Chatacterisation Tests on Bond Coats: Worldwide Study, Impact, Tests, and Recommendations, $3^{\text {rd }}$ International Conference Bituminius Mixtures and Pavements, Thessaloniki, 2002.

\section{Conclusion}

The analysis of the asphalt layer bonding strength has revealed that, in all cases, the bonding strength was greater than $25 \mathrm{kN}$ after 10 days of asphalt compaction, while the shear flow was greater than 1,5 mm.

The shear force results for samples with the $100 \%$ compaction of asphalt wearing course were 13\% (AC $11 \mathrm{VN}$ ) and $18 \%$ (AC 11 VS) higher when compared to the $97 \%$ compaction level. The values of all samples made of the asphalt wearing course type AC 11 VN were higher by av. $26 \%$ (tested after 2 days) and av. $54 \%$ (tested after 10 days), when compared to the values of the asphalt wearing course made of AC 11 VS. In this case, the bitumen emulsion was not used in the interlayer.

The experimental research has shown that the bonding strength between asphalt layers decreases from $20 \%$ to 50 $\%$ when the geogrid is laid between asphalt layers. The use of geosynthetics also contributes to the reduction of shear flow. It was also established that the quantity of bonding emulsion C 60 BF 1-S influences the shear force exerted on asphalt layers. Thus, shear force values ranged from $22,8 \mathrm{kN}$ to $32,7 \mathrm{kN}$ (tested after 2 days), and from $32,7 \mathrm{kN}$ to $44,8 \mathrm{kN}$ (tested after 10 days). The bonding strength was by about $30 \%$ greater with bitumen emulsion present in asphalt interlayer, when compared to the situation without the emulsion (tested after 2 days), while the difference was not significant after 10 days.

[8] Dübner, R., Glet, W.: Unterhaltung von Asphaltstraßen Arbeitsgemeinschaft der Bi-tumen-Industrie, e.V., Hamburg, 1993.

[9] Tashman, L., Nam, K., Papagiannakis, T.: Evaluation of the Influence of Tack Coat Construction Factors on the Bond Strength Between Pavement Layers, Report\# WCAT 06-002, Washington Center for Asphalt Technology, 2006.

[10] Vaitkus, A., Žilionienè, D., Paulauskaitè, S., Tuminienè, F., Žiliūtè, L.: Research and Assessment of Asphalt Layers Bonding, The Baltic Journal of Road and Bridge Engineering, 6(3), p.p. 210218, 2011. ISSN 1822-427X (print), ISSN 1822-4288 (online). (Thomson ISI Web of Science).

[11] Vaitkus, A., Puodžiukas, V., Motiejūnas, A., Vitkienè, J., Vorobjovas, V., Paliukaite, M.: Long Term Research of Experimental Asphalt Pavement Structures, in Transport Research Arena Europe 2010, Brussels: Selected papers (2010, Brussels, Belgium).

[12] Čygas, D., Laurinavičius, A., Vaitkus, A., Perveneckas, Z., Motiejūnas, A.: Research of asphalt pavement structures on Lithuanian roads (I), The Baltic Journal of Road and Bridge Engineering, 3(2), p.p. 77-83, 2008. ISSN 1822-427X (print), ISSN 1822-4288 (online). (Thomson ISI Web of Science).

[13] Leutner, R.: Untersuchungen des Schichtenverbunds beim bituminösen Oberbau Investigation of the Adhesion of Bituminius Pavements], Bitumen 3, p.p. 84-91, 1979.

[14] Forschungsgesellschaft für Straßen- und Verkehrswesen, Zusätzliche Technische Vertragsbedingungen und Richtlinien für den Bau von Verkehrsflächenbefestigungen aus Asphalt ZTV Asphalt-StB 07. 2007. 